\title{
Discourse Analysis of News Narrative Based on Cognitive Model Theory
}

\author{
Yang ZhiShang \\ Changsha Medical University, Changsha, Hunan,413000 China \\ 284204813@qq.com
}

Keywords: Cognitive Linguistics; Idealized Cognitive Model; Event-domain Cognitive Model; News Narrative

\begin{abstract}
From the perspective of cognitive linguistics, based on Lakoff's idealized cognitive model theory and Wang Yin's event-domain cognitive model theory, we explain the generic features of news narrative discourse from a macro perspective in order to expand the research field of cognitive linguistics and try to provide a new analysis perspective for news narrative discourse.
\end{abstract}

\section{Introduction}

Since the 1990s, narratology has been combined with cognitive science and cognitive linguistics in theory and application, which has done an important contribution to the revival of narratology in its unique way of narrative research. Compared with foreign researches, the research of narrative from the perspective of cognitive linguistics was started in twenty-first Century in China, mainly focused on the interpretation of literary narrative, rhetorical narrative and on the application of narratology to literary works, television, film works and so on. The study of news texts mostly focuses on their linguistic structures and characteristics, using the theories of systemic functional linguistics and critical discourse analysis. At present, it is rare to apply cognitive linguistics to news narrative discourse.

\section{The typical analysis of cognitive frame}

The complicated terminologies really bring a lot of inconvenience for describing and understanding the concept of frame. The key points of plot, schematism and script are totally different, while the context is still considered as "framework" for general terms of natural language understanding, including "schema, script, scenario, meaning support, cognitive model or folk theory". 
Table 1 Frame terminologies of different disciplines

\begin{tabular}{|c|c|c|c|c|c|}
\hline \multicolumn{6}{|l|}{ Frame } \\
\hline $\begin{array}{l}\text { Representing } \\
\text { researchers }\end{array}$ & $\begin{array}{l}\text { Minsky 1975, } \\
1977\end{array}$ & $\begin{array}{l}\text { Fillmore } \\
1975,1977\end{array}$ & $\begin{array}{l}\text { Fillmore } \\
1982\end{array}$ & Tannen 1993- & $\begin{array}{l}\text { annen \& Wal } \\
\text { lat }\end{array}$ \\
\hline 1993 & $\begin{array}{l}\text { The upper and } \\
\text { lower layers of } \\
\text { the terminal } \\
\text { (slots vacancy) } \\
\text { are full of } \\
\text { default task } \\
\text { assignments(19 } \\
77: 355)\end{array}$ & $\begin{array}{l}\text { A schema } \\
\text { frame with } \\
\text { spaces } \\
\text { (blanks)(1977 } \\
: 72)\end{array}$ & $\begin{array}{l}\text { The abstract } \\
\text { expectation } \\
\text { structure } \\
\text { with role, } \\
\text { purpose and } \\
\text { order of } \\
\text { events(1982: } \\
117)\end{array}$ & $\begin{array}{l}\text { Organized } \\
\text { knowledge } \\
\text { characterized in } \\
\text { the form of } \\
\text { expectation(1993 } \\
: 21)\end{array}$ & $\begin{array}{l}\text { Consisting of } \\
\text { verbal and } \\
\text { nonverbal } \\
\text { behaviors(1993 } \\
: 60)\end{array}$ \\
\hline Structure & $\begin{array}{l}\text { The upper and } \\
\text { lower layers of } \\
\text { the terminal } \\
\text { (slots vacancy) } \\
\text { are full of } \\
\text { default task } \\
\text { assignments(19 } \\
77: 355)\end{array}$ & $\begin{array}{l}\text { A schema } \\
\text { frame with } \\
\text { spaces } \\
\text { (blanks)(1977 } \\
: 72)\end{array}$ & $\begin{array}{l}\text { The abstract } \\
\text { expectation } \\
\text { structure } \\
\text { with role, } \\
\text { purpose and } \\
\text { order of } \\
\text { events(1982: } \\
117)\end{array}$ & $\begin{array}{l}\text { Organized } \\
\text { knowledge } \\
\text { characterized in } \\
\text { the form of } \\
\text { expectation(1993 } \\
: 21)\end{array}$ & $\begin{array}{l}\text { Consisting of } \\
\text { verbal and } \\
\text { nonverbal } \\
\text { behaviors(1993 } \\
: 60)\end{array}$ \\
\hline $\begin{array}{l}\text { Typical } \\
\text { Features }\end{array}$ & $\begin{array}{l}\text { cognitive and } \\
\text { psychological }\end{array}$ & Linguistic & $\begin{array}{l}\text { cognitive and } \\
\text { psychologica } \\
1\end{array}$ & $\begin{array}{l}\text { cognitive and } \\
\text { psychological }\end{array}$ & $\begin{array}{l}\text { Interactive and } \\
\text { pragmatic }\end{array}$ \\
\hline Type & $\begin{array}{l}\text { Syntax, } \\
\text { semantics, } \\
\text { theme, } \\
\text { narrative } \\
\text { framework }\end{array}$ & $\begin{array}{l}\text { The collection } \\
\text { of words, } \\
\text { grammatical } \\
\text { choice and } \\
\text { linguistic } \\
\text { category }\end{array}$ & $\begin{array}{l}\text { Interactive } \\
\text { frame (how } \\
\text { speakers and } \\
\text { listeners } \\
\text { conceptualiz } \\
\text { e the things } \\
\text { that } \\
\text { happened), } \\
\text { cognitive } \\
\text { frame }\end{array}$ & $\begin{array}{l}\text { Events, goals, } \\
\text { people, levels: } \\
\text { context, } \\
\text { communication } \\
\text { act, content }\end{array}$ & $\begin{array}{l}\text { Examples: } \\
\text { social } \\
\text { encounters, } \\
\text { medical } \\
\text { examinations, } \\
\text { counseling }\end{array}$ \\
\hline
\end{tabular}


Table 2 Frame terminologies within linguistics

\begin{tabular}{|c|c|c|c|c|}
\hline terminologies & scene & schema & script & scenario \\
\hline $\begin{array}{l}\text { Representing } \\
\text { researchers }\end{array}$ & $\begin{array}{l}\text { Fillmore 1975, } \\
1977\end{array}$ & $\begin{array}{l}\text { Tannen\&Wallat1 } \\
993\end{array}$ & $\begin{array}{l}\text { Schank\&Abelson } 19 \\
77\end{array}$ & Sanford \& Garrod1977 \\
\hline Definition & $\begin{array}{l}\text { "Any type of } \\
\text { human belief, } \\
\text { behavior, } \\
\text { expectation, or } \\
\text { imagination(197 } \\
\text { 5: 124) }\end{array}$ & $\begin{array}{l}\text { "Expectations and } \\
\text { assumptions about } \\
\text { the Gan } \\
\text { circle"(1993: 73) }\end{array}$ & $\begin{array}{l}\text { "A predetermined } \\
\text { sequence of } \\
\text { stereotypes used to } \\
\text { define a well-known } \\
\text { situation"( } 1977: 41)\end{array}$ & $\begin{array}{l}\text { "A reference domain of } \\
\text { an } \\
\text { extend"1983:(Brown\&Y } \\
\text { ule81) Concrete scenario }\end{array}$ \\
\hline Structure & $\begin{array}{l}\text { Consisting of } \\
\text { entities, } \\
\text { relations, or } \\
\text { substances(Com } \\
\text { pared with 1977: } \\
81)\end{array}$ & $\begin{array}{l}\text { No specific } \\
\text { structure is given }\end{array}$ & $\begin{array}{l}\text { "Consists of spaces } \\
\text { and requirements for } \\
\text { filling the } \\
\text { spaces"(1977: 42ff) }\end{array}$ & $\begin{array}{l}\text { psychological and } \\
\text { cognitive (Compared } \\
\text { with:Brown\&Yule1983: } \\
\text { 245) }\end{array}$ \\
\hline
\end{tabular}

The essence of the frame is as followed: When we meet a scenario, that people choose from memory is the structure of a frame. This is a remembered frame for matching in reality and changing details if necessary. A frame is a data structure used to represent routine situations, such as living room scenes or children's birthday parties. There are several kinds of information associated with each frame, and others are expected to happen next. 
Move structure, the features of the move structures are as followed:

Table 3: Sub-mark sheet of move structure

\begin{tabular}{|c|c|c|c|c|c|c|c|c|c|c|}
\hline & M1 & M2S1 & M2S2 & M3S3 & M3S1 & M3S2 & M3S3 & M4S1 & M4S2 & M4S3 \\
\hline S1 & $*$ & $*$ & & $*$ & $*$ & & $*$ & & $*$ & \\
\hline S2 & $*$ & $*$ & $*$ & $*$ & $*$ & & & $*$ & & \\
\hline S3 & $*$ & $*$ & & $*$ & $*$ & & $*$ & $*$ & & \\
\hline S4 & $*$ & $*$ & & $*$ & $*$ & & & $*$ & & \\
\hline S5 & $*$ & $*$ & & $*$ & $*$ & & & & $*$ & \\
\hline S6 & $*$ & $*$ & & $*$ & $*$ & & & $*$ & & \\
\hline S7 & $*$ & $*$ & & $*$ & $*$ & & & & & \\
\hline S8 & $*$ & $*$ & $*$ & $*$ & $*$ & & & $*$ & & \\
\hline S9 & $*$ & $*$ & & $*$ & $*$ & & & $*$ & & \\
\hline S10 & * & $*$ & $*$ & $*$ & $*$ & & & $*$ & & \\
\hline S11 & $*$ & $*$ & $*$ & $*$ & $*$ & & & & & \\
\hline S12 & $*$ & $*$ & & $*$ & $*$ & & & & & \\
\hline S13 & $*$ & $*$ & & $*$ & $*$ & $*$ & & $*$ & & \\
\hline S14 & $*$ & $*$ & $*$ & $*$ & $*$ & $*$ & & $*$ & & \\
\hline S15 & $*$ & $*$ & & $*$ & $*$ & $*$ & & & & $*$ \\
\hline S16 & $*$ & $*$ & & $*$ & $*$ & & & $*$ & & \\
\hline S17 & $*$ & $*$ & & $*$ & $*$ & $*$ & & & & \\
\hline S18 & $*$ & $*$ & & $*$ & $*$ & & & $*$ & & \\
\hline S19 & $*$ & $*$ & & $*$ & $*$ & & & $*$ & & \\
\hline S20 & $*$ & $*$ & & $*$ & $*$ & & & $*$ & & \\
\hline S21 & $*$ & $*$ & & $*$ & $*$ & & & $*$ & & \\
\hline $\mathrm{S} 22$ & $*$ & $*$ & & $*$ & $*$ & & & $*$ & & \\
\hline S23 & $*$ & $*$ & & $*$ & $*$ & & & $*$ & & \\
\hline S24 & $*$ & $*$ & & $*$ & & & & & $*$ & \\
\hline $\mathrm{S} 25$ & $*$ & $*$ & & $*$ & $*$ & $*$ & & $*$ & & \\
\hline S26 & $*$ & $*$ & & $*$ & $*$ & $*$ & & $*$ & & \\
\hline S27 & $*$ & $*$ & & $*$ & $*$ & & & & $*$ & \\
\hline S28 & $*$ & $*$ & & $*$ & $*$ & & & $*$ & & \\
\hline S29 & $*$ & $*$ & & $*$ & $*$ & & & $*$ & & \\
\hline S30 & $*$ & $*$ & & $*$ & $*$ & & & $*$ & & \\
\hline S31 & $*$ & $*$ & & $*$ & $*$ & & & & $*$ & \\
\hline S32 & $*$ & $*$ & & $*$ & $*$ & & & $*$ & & \\
\hline S33 & $*$ & $*$ & & $*$ & $*$ & & & $*$ & & \\
\hline S34 & $*$ & $*$ & & $*$ & $*$ & & & $*$ & & \\
\hline S35 & $*$ & $*$ & & $*$ & $*$ & & & $*$ & & \\
\hline Per. & $100 \%$ & $100 \%$ & $34 \%$ & $100 \%$ & $94 \%$ & $17 \%$ & $40 \%$ & $74 \%$ & $14 \%$ & $3 \%$ \\
\hline
\end{tabular}

As shown in figure, the percentage of occurrence frequency of move 1 is $100 \%$, the frequency percentages of move 2,3 , and 4 are $100 \%, 97 \%$ and $91 \%$ respectively after further calculation. Then for each move, in move 2 , the frequency percentages of step $1,2,3$ are respectively $100 \%, 34 \%$, $100 \%$; in move 3 , the frequency percentages of step $1,2,3$ are respectively $94 \%, 17 \%, 40 \%$; in move 4 , the frequency percentages of step $1,2,3$ are respectively $74 \%, 14 \%, 3 \%$. The data show that in the cognitive model theory of news narrative discourses, move 2 "is main subject", move 1 is "to clarify the background information and move 3 is "reported object", which less reveal the subsequent development of forecast events; move 3 is releasing events by step 1 "from the point of view on", followed by step 2 "exposing events", and finally to step 3 "events evaluation"; move 4 is mainly 
using step 1 to "extend topic information", followed by step 2 "discussing the theme of the text", " and step 3 to "point out the source".

The following is a detailed explanation of the steps and steps of the distribution.

The concept of news narrative discourse instantiation and the feature of online processing characteristics of language in working memory are the goal of the cognitive model theory. The goal is the process of language generation: all relevant information is presented at the moment, as shown in the following figure:

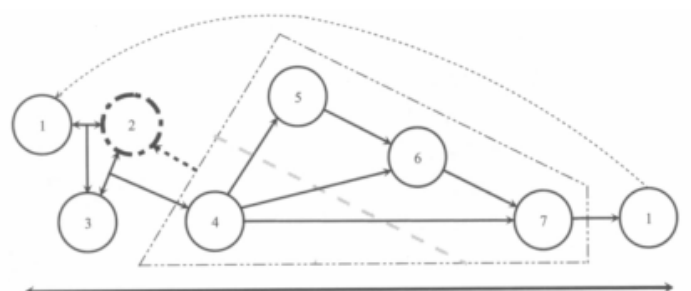

Figure 1. Sketch map of the process of news narrative language

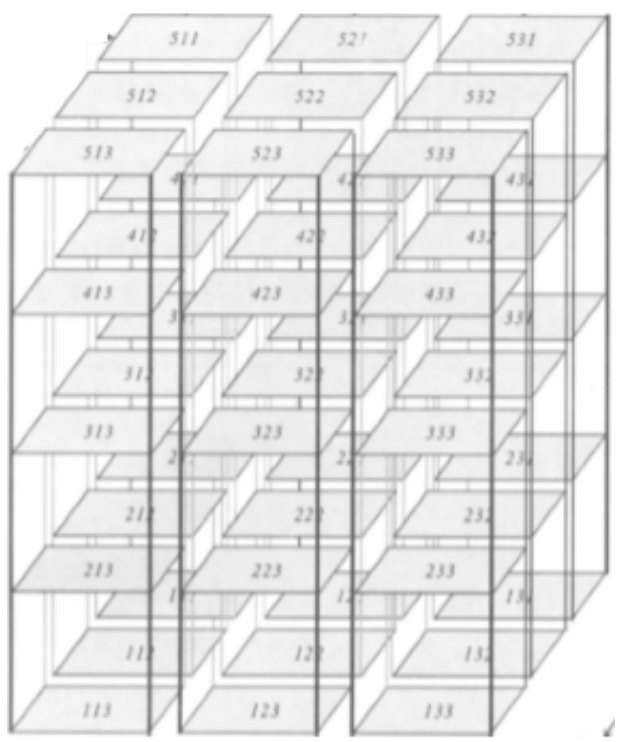

Figure 2. The multidimensional model of news narrative language

\section{Event-domain cognitive model and news narrative}

Aiming at the shortcomings of Billiard-ball Model of Langacker's, Stage Model, Force-Dynamic Model of Talmy's, Spatialization of Form Hypothesis of Lakoff's and "Script theory" of Schank \& Abelson( 1975), Wang Yin proposed ECM as a part of cognitive model theory to study causes of formation, conversion of parts of speech, changing of word meaning, antonym and indirect speech act. Wang Yin believes that "ECM as a more general and applicable cognitive model, also applies to syntax, text, pragmatics and other aspects of analysis." The basic idea of ECM is like the following graph (the border of the event-domain is represented by dashed lines because one event is difficult to make a clear distinction from another.):

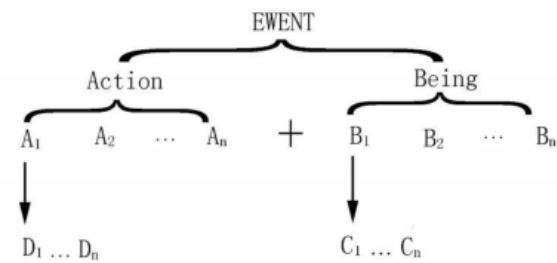

Figure 3. Event-domain cognitive model map 
$\mathrm{CM}$ believes that people often experience and understand the world in the domain of events, and store them in the brain as knowledge, which is in full accordance with people's general cognitive law. Based on the experience and cognition of many concrete events, people gradually abstract the conceptual structure of events, and gradually form various expressions in the language. Each element in a ECM presents a hierarchical relationship (as shown in Figure 3).

In the first level: an event mainly includes the action elements (Action, including dynamic behaviors and static behaviors) and being elements (Being, including people, things, tools and other entities and abstract or virtual concepts); in the second level: these two elements also include many sub elements (Action is formed by A1, A2 and An, Being is formed by B1, B2 and Bn); in the third level: each sub element includes a lot of typical information such as characteristics and classification of information D or C.

An event may include many action elements and being elements. In event domain $\mathrm{E}$ that the plane hit the floor, including multiple actions such as driving aircraft, low altitude flight, crashing into the building, catching fires and IRS employees escaping from the building. In the event of domain $\mathrm{E}$ is also involved in a number of beings such as pilots, aircrafts, tax building, IRS employees etc. According to conventional human experience and cognitive, combined with the existing rules between actions and beings, a series of BAB collocation become the knowledge in the minds of people, such as pilots driving aircrafts, the aircrafts crashing into the building, the building catching fire and evacuation of employees.

In the domain $\mathrm{E}$ of the whole driving aircraft hitting into the building, each element appears as hierarchical relations, and the core action in the prominent position is crashing into the building, the core beings are pilots, aircraft and building. Secondly, the typical characteristics D of driving information includes time (Thursday morning / 18th), location (AUSTIN, Tex.), reason (strongly dissatisfied with the tax bureau) etc. With the depth of coverage information, the concrete modification information $C$ are pilots, aircrafts, the specific features of the building are: Joseph Stark, the pilot is 53 years old, who was a software engineer and belonged to the high income crowd but died on the spot in crash; the aircraft is light private plane belonged to Stark himself; the building is the tax building with nearly more than 200 employees, which had a fire after the incident. Of course, D or C may also be characterized by sub event domains. Such as the reason D is that Stark (B) is dissatisfied (A) with the tax department (B); the feature $C$ of being pilot is that Stark (B) belongs to (A) the high income group (B); the characteristics $\mathrm{C}$ of aircraft is that aircraft $(\mathrm{B})$ is $(\mathrm{A})$ his private light plane etc.

Also, in the news event, the events at the center of the core domain (core ECM: pilot drives the airplane crashing into the building) and peripheral event domain (peripheral ECM) is a hierarchical relationship with diffusion characteristics. These peripheral event domains are:

(1) the background ECM: Stark grew up in the orphanage; he struggled with the tax authorities for 20 years; he and his wife divorced; (2) Preparation ECM: he set fire to his own homes; he attacked the tax department online; (3) action ECM: NORAD dispatched two F-16 fighter jets over Austen to cruise. National Transportation Safety Board has sent staff to the scene investigation; President Obama listened to the incident report; (4) evaluation ECM: White House spokesman Robert Gibbs, Republican Mccall, director of the accident at the scene of Austen city police have issued statements; evaluation of relatives, friends and colleagues; (5) similar incidents ECM: in 1995, Mike Vine blow up a federal building of Oklahoma because of dissatisfaction of taxation system; in 2007, Edward Brown and his wife refused to pay tax with violence; (6) reflection ECM: high income earners in America is dissatisfied with the government's collection of personal income taxes; public concerns about aviation safety, etc..

Combining cognitive linguistics with narratology, this paper attempts to explore the linguistic features of news narrative texts at the macro level from the perspective of idealized cognitive models and event-domain cognitive models. 


\section{References}

[1] Zhang Yan. The Image Presentation and Aesthetics Turn of Data News[J]. Editors' Friend,2015,03:85-88.

[2] Li Yan, Li Saike. Tell a Good Story? How Data Journalism Inherits and Transforms Traditional Journalism[J]. Journal of Zhejiang University (Humanities and Social Sciences), 2015, 06:106-128.

[3] Li Xin.Schema Understanding: Cognitive Mechanism and Narrative Meaning of Minority Journalism[J]. Contemporary Communication, 2016,04:57-60.

[4] Yang Guang, Gou Zhongshi. News Content, Understanding and Memory: A Mental Model for Comprehending the Coverage of Controversial Issues[J]. Journalism \& Communication, 2016, 11:35-50+126-127.

[5] Chu Jun. The Metaphor Interpretation of Narrative News Headline from the Perspective of Narrative Approach[J].Foreign Language World,2012,01:90-95. 